\title{
Nucleotide sequence variation in isolates of infectious salmon anaemia virus (ISAV) from Atlantic salmon Salmo salar in Scotland and Norway
}

\author{
J. A. Inglis, J. Bruce, C. O. Cunningham* \\ FRS Marine Laboratory, PO Box 101, Victoria Road, Aberdeen AB11 9DB, United Kingdom
}

\begin{abstract}
The nucleotide sequences of segments 2 and 8 of infectious salmon anaemia virus (ISAV) isolates from Scotland and Norway were determined and compared. Sequence variations were found in both segments, with segment 2 being more variable. These variations were of the same degree as those found in previous comparisons of the first recorded strain of ISAV in Scotland and Norwegian strains for which sequence information was available. The sequences again demonstrate the separation of European and Canadian strains of ISAV but, as is expected for an RNA virus, reveal that the European ISAV is not homogeneous. These results demonstrate the value of nucleotide sequences as a tool for strain identification and epidemiological investigation of ISAV.
\end{abstract}

KEY WORDS: Infectious salmon anaemia virus · ISAV . Atlantic salmon $\cdot$ Salmo salar $\cdot$ Nucleotide sequence

Resale or republication not permitted without written consent of the publisher

Infectious salmon anaemia (ISA) was first reported in Norway in the Autumn of 1984 in farmed Atlantic salmon Salmo salar L. (Thorud \& Djupvik 1988). Since then it has also been reported in Canada, and more recently in Scotland in 1998 (Mullins et al. 1998, Rodger et al. 1998, Stagg et al. 1999), and has caused substantial economic hardship to the Atlantic salmon farming industry.

The ISA virus is an enveloped virus consisting of a single-stranded RNA genome with 8 segments of negative polarity (Falk et al. 1997). Each segment ranges in size from 1.0 to $2.3 \mathrm{~kb}$ with the total molecular weight of the genome being $14.5 \mathrm{~kb}$ (Mjaaland et al. 1997). ISA virus (ISAV) displays a strong similarity to members of the Orthomyxoviridae family of viruses. Previous nucleotide sequence analysis has revealed variations in isolates from different countries (Blake et

${ }^{*}$ Corresponding author. E-mail: cunninghamc@marlab.ac.uk al. 1999, Cunningham \& Snow 2000). Other members of the Orthomyxoviridae, such as influenza viruses, exhibit rapid mutation rates in some genes (Krystal et al. 1983, Nakajima et al. 1987, Suarez \& Perdue 1998). Determining the rate of variation in ISAV genes is important for several reasons. For epidemiological study, different strains and mutations can provide a means of tracking the spread of certain variants of the virus. They can also be useful in assessing possible sources of infection. Different strains can have different pathogenicity and may result in different presentation of the disease, as illustrated by the predominance of 'haemorrhagic kidney' pathology in Canadian cases of ISAV, whereas hepatic necrosis was considered of greater importance in Norwegian samples. Strain identification is therefore important for management of the disease. Vaccine development and application also requires knowledge of strain variations, as the protective effect of a vaccine can vary significantly if different strains of the virus are present. It has been stated that Norwegian isolates of ISAV display varying nucleotide sequences (see Hastings et al. 1999), but the data on which this statement was based have not been released. In this study, several isolates of ISAV were examined by nucleotide sequencing to determine the extent of genetic variation within a country and between countries.

Scottish isolates 390/98 and 1490/98 were obtained from $1 \mathrm{~g}$ kidney sampled from farmed Atlantic salmon Salmo salar and placed in $10 \mathrm{ml}$ transport solution (Earle's balanced salt solution $1 \times$, fungizone $5 \mu \mathrm{g} \mathrm{ml}^{-1}$, polymixin B $200 \mathrm{U} \mathrm{ml}^{-1}$ and kanamycin $200 \mathrm{\mu g} \mathrm{m}^{-1}$; (Life Technologies, Paisley, UK). Norwegian ISAV strains Sotra/B797/92, Hinnøy/2264/93 and Bømlo/228/98 isolated from Atlantic salmon in 1992, 1993 and 1998, respectively, were received from the National Veteri- 
nary Institute, Oslo. ISAV was cultured in salmon head kidney cells as described by Dannevig et al. (1995). Cell supernatant was removed from a well of a tissue culture plate and $800 \mu \mathrm{l}$ of TRIzol (Life Technologies) added. Cells were scraped from the surface of the plate and removed to a $1.5 \mathrm{ml}$ microfuge tube. RNA was extracted using TRIzol in accordance with the manufacturers' method. The optical density at 260 and $280 \mathrm{~nm}$ was recorded to determine the concentration and purity of the extracted RNA.

An aliquot of $2 \mu \mathrm{g}$ RNA was converted to DNA by reverse transcriptase as described by Mjaaland et al. (1997) using MMLV-RT (Life Technologies). An aliquot of $5 \mu \mathrm{l}$ CDNA was added to $45 \mu \mathrm{l}$ PCR mix which contained $1 \times$ Reaction Buffer (Bioline, London, UK) $1.5 \mathrm{mM} \mathrm{MgCl}, 0.2 \mathrm{mM}$ dNTPs (each) (Life Technologies), 2 U of Taq polymerase (Bioline), $28 \mathrm{pmol}$ of each primer and diethyl pyrocarbonate (DEPC)-treated distilled water. All reactions were over-laid with mineral oil (Sigma, Poole, Dorset, UK). An 878 bp fragment of segment 8 was amplified using primers ISA+ (5'-GGCTATCTACCATGAACGAATC3') (Mjaaland et al. 1997) and ISA R1 (5'-TCTTTTGTATAATGATCAAGTACAC-3'). This reaction was subjected to 35 cycles of $94^{\circ} \mathrm{C}$ for $30 \mathrm{~s}, 55^{\circ} \mathrm{C}$ for $30 \mathrm{~s}$ and $72^{\circ} \mathrm{C}$ for $1 \mathrm{~min}$ in a thermocycler (Techne, Cambridge, $\mathrm{UK})$.

Segment 2 was amplified in 2 parts. These 2 overlapping fragments were amplified using primer set A with downstream primer PB1 (5'-CGTAGATGCCGT-TGTAAAAGC-3') (Blake et al. 1999) and upstream primer (5'-GCAAGAACGCTCTTTAATAACC-3') and primer set B with upstream primer (5'-GAGAGCATGTGCCCAGAAGTGAT-3') and downstream primer (5'-CGTCAATTCCGTTATTACACACAG-3'). Both primer sets were used in reactions subjected to 35 cycles of $94^{\circ} \mathrm{C}$ for $1 \mathrm{~min}, 55^{\circ} \mathrm{C}$ for $1 \mathrm{~min}$ and $72^{\circ} \mathrm{C}$ for $1 \mathrm{~min}$.

Three replicate amplifications were carried out for each isolate to eliminate PCR misincorporations in the final sequences. All PCR products were visualised by electrophoresis on a $1 \%(\mathrm{w} / \mathrm{v})$ agarose gel stained with ethidium bromide and viewed under UV transillumination. PCR products were purified using Wizard PCR Preps (Promega, Southampton, UK) or Geneclean III (Bio 101, Vista, CA, USA) and were quantified on a $1 \%$ agarose gel alongside mass markers of known molecular weight.

Segment 8 was sequenced in both forward and reverse orientation using the original PCR primers (Mjaaland et al. 1997). The sequence of segment 2 was completed in both orientations using internal primers where necessary. Sequencing was performed using the dRhodamine Terminator Ready Reaction Mix and electrophoresis on an ABI 377 automated DNA sequencer (Perkin Elmer, Warrington, UK). Alignment of resulting sequences was carried out using Sequencher software (Gene Codes Corporation, Ann Arbor, MI, USA). Once a consensus nucleotide and putative protein sequence was achieved for each sample, comparisons were made with sequences already available on the European Molecular Biology Laboratory (EMBL) nucleotide database. These were Norwegian isolates Sotra 92/93 segment 2 (AJ002475), and Glesvaer/90 segment 8 (AJ012285), Canadian Bliss Harbor 8/97 isolate segments 2 (AF095254) and 8 (AF095255), and Fundy strain segment 8 (AF109304), and Scottish farm isolate 390/98 segment 2 (AJ242808) and segment 8 (AJ242016). Sequence alignment was performed using ClustalW (Thompson et al. 1994).

Sequences of the Scottish and Norwegian isolates showed variation in the nucleotide sequences, most significantly in segment 2 (Table 1). Isolate 1490/98 from Atlantic salmon in Scotland had segment 8 sequence that was identical to that of the Norwegian Glesvaer/90 isolate (AJ012285), but showed 3 nucleotide differences when compared with the original Scottish isolate (AJ242016) (Cunningham \& Snow 2000).

Table 1. Segment 2 nucleotide (above diagonal) and amino acid (below diagonal) sequence identity between ISAV isolates from Scotland (AJ242808, 1490/98), Norway (AJ002475, Sotra/B797/92, Hinnøy/2264/93 and Bømlo/228/98) and Canada (AF095254)

\begin{tabular}{|c|c|c|c|c|c|c|c|}
\hline & \multicolumn{2}{|c|}{ Scotland -} & \multirow[b]{2}{*}{ AJ002475 } & \multicolumn{2}{|c|}{ _ Norway } & \multirow[b]{2}{*}{ Bømlo } & \multirow{2}{*}{$\begin{array}{c}\text { Canada } \\
\text { AF095254 }\end{array}$} \\
\hline & AJ242808 & $1490 / 98$ & & Sotra & Hinnøy & & \\
\hline \multicolumn{8}{|l|}{ Scotland } \\
\hline AJ242808 & - & 98.93 & 99.23 & 99.40 & 98.78 & 99.39 & 83.84 \\
\hline $1490 / 98$ & 98.84 & - & 98.65 & 98.79 & 98.81 & 98.91 & 83.49 \\
\hline \multicolumn{8}{|l|}{ Norway } \\
\hline AJ002475 & 98.84 & 99.13 & - & 99.73 & 98.46 & 99.06 & 83.58 \\
\hline Sotra & 99.28 & 99.57 & 99.57 & - & 98.74 & 99.39 & 84.01 \\
\hline Hinnøy & 99.28 & 99.57 & 99.57 & 100 & - & 98.77 & 83.84 \\
\hline Bømlo & 98.99 & 99.28 & 99.28 & 99.71 & 99.71 & - & 83.84 \\
\hline \multicolumn{8}{|l|}{ Canada } \\
\hline AF095254 & 96.61 & 97.13 & 96.61 & 97.39 & 97.39 & 97.39 & - \\
\hline
\end{tabular}


When the new Scottish isolate was compared with Norwegian strains Sotra/B797/92, Hinnøy/2264/93 and Bømlo/228/98, there were 3, 2 and 3 nucleotide differences, respectively, found at the same positions as the differences between the new and original Scottish isolates. None of these changes produced alterations in the predicted protein sequence.

Analysis of segment 2 from the new Scottish isolate showed $98.93 \%$ nucleotide sequence similarity with the original Scottish isolate (AJ242808), 98.65\% similarity with the Norwegian isolate (AJ002475) and $83.49 \%$ similarity with the Canadian isolate (AF095254). This is equivalent to 23 and 29 differences in the 2150 nucleotide alignment of Scottish and Norwegian sequences and 190 differences in the alignment with 1151 nucleotides of the Canadian sequence. The use of the sequence alignment programme allowed closer examination of the relationships between the various isolates (Fig. 1). Within the European isolates, nucleotide variation in segment 2 resulted in changes in 12 out of 692 amino acids, with a change of character occurring at 7 of these amino acid positions along the length of the protein. None of the variation was found in the polymerase motif regions (Krossøy et al. 1999). However, the Canadian isolate showed a far higher degree of sequence variation, including 2 amino acid differences in polymerase motif region $\mathrm{B}$. There were greater differences between the Canadian and European isolates than among the European isolates. The degree of variation between the Norwegian and Scottish isolates was similar to the degree of variation within each country. Phylogenetic analysis did not show any consistent relationships between the various ISAV isolates due to the low number of variable nucleotides between these sequences.

RT-PCR is a well-established technique for the diagnosis of ISAV (Rimstad et al. 1999). It is a sensitive method that can be carried out rapidly. An increased knowledge of the nucleotide sequence of the ISAV genome has allowed the comparison of different isolates from different countries (Blake et al. 1999, Cunningham \& Snow 2000) and so RT-PCR followed by sequencing has proved to be a useful tool in epidemiological studies.

ISA has been suggested to spread by horizontal but not vertical transmission (Thorud \& Djupvik 1998, Melville \& Griffiths 1999). This horizontal transmission can occur through moving infected fish, proximity to infected farms, uncontrolled towing of cages, contaminated discharge from fish processing units and the movement of well-boats from site to site (Jarp \& Karlsen 1997). To date in Scotland, confirmed cases of ISAV in fish farms have been traced back to a particular point source and there is evidence of the spread of the virus from site to site. The nucleotide sequence from the original outbreak was identical to that of sites subsequently confirmed as infected (Cunningham \& Snow 2000). The results presented here reveal other variant sequences of ISAV segments within Scottish waters, as well as variants within Noray. In the case of the site from which isolate 1490/98 was obtained, the fish were being harvested when the samples were taken. Thus, it is not known whether an outbreak of ISA would have occurred on this site or whether this isolate of the virus is less pathogenic.

The degree of variation in the sequences presented here is small. The Scottish sequences resembled those from Norwegian isolates to a greater extent than those from Canadian isolates. This reinforces previous results that indicated a closer relationship between the Norwegian and Scottish isolates than between the European and Canadian isolates (Blake et al. 1999, Cunningham \& Snow 2000). There was insufficient sequence variation for satisfactory phylogenetic analysis. However, once further isolates have been obtained and sequenced, more informative positions may be obtained, making such analysis possible.

Influenza virus sequences show cumulative changes along common lineages (Krystal et al. 1983). The PB1 gene (encoded by segment 2 in ISAV) exhibits the second highest rate of silent mutations, whereas the NS gene (equivalent to ISAV segment 8) has a low rate of mutation. From the limited amount of information available on ISAV sequence variation, it would appear that this virus follows a similar pattern, although, as yet, there is insufficient information to allow speculation on lineages. For the purposes of epidemiological study, ISAV segment 2 appears to be an appropriate choice for examination. Once further segments of the virus have been isolated, the neuraminindase gene, found to be slightly more variable than PB1 in influenza (Krystal et al. 1983), may also be useful. In the Norwegian isolates, there is $0.61 \%$ nucleotide variation between the 1992 Sotra isolate and the 1998 Bømlo isolate. Extrapolation from this figure to estimate the mutation rate of ISAV reveals a 10 -fold lower divergence of the PB1 gene in ISAV compared with influenza. The NS gene of avian influenza shows 0.12 to $0.34 \%$ variation $\mathrm{yr}^{-1}$ (Nakajima et al. 1987), similar to the rate of $0.1 \%$ for ISAV segment 2 estimated in this study. ISAV segment 8 , which is equivalent to the influenza NS, shows an even lower rate of divergence with only 3 nucleotide differences between the isolates. Due to the nature of the marine environment, the dynamics of orthomyxovirus infection may follow a different pattern in fish than in terrestrial hosts. Transmission of viruses from host to host will occur at a relatively low rate between wild salmonids. This will be reflected in a low rate of sequence diver- 
AJ 242808

AJO0 14975

ILA 8

I LA 10

AF 095254

AJ 242808

$1490 / 98$
AJO0O2475

ILA 8

I LA 10

AF 095254

AJ 242808

$1490 / 98$
AJOOOL2475

ILA 8

I LA 10

AFO 05254

AJ 242808

$1490 / 98$

ILA 8

ILA10

ILA 36
AF 095254

AJ2 42808

$1490 / 98$

AJO 02475

ILA 8

I LA 10
I LA 36

I LA 36
AF 095254

AJ2 42808

$1490 / 98$

AJ 002475

ILA 8

I LA 10

AFO 95254

AJ2 42808

$1490 / 98$
AJOOO2475

ILA 8

I LA 10

AF 095254

AJ2 42808

$1490 / 98$

ILA 8

ILA10

I LA 36
AF 095254

AJ 242808

$1490 / 98$
AJO 02475

ILA 8

ILA10

ILA36

AF 095254

AJ2 42808

$1490 / 98$
AJ 002475

ILA 8

I LA 10

I LA 36
AF 095254

AJ2 42808

$1490 / 98$

AJ 002475

ILA 8

I LA 10

AF 095254
SMSNDVSCLYVYD GP MRVF S QNALMP T LQSVKRSD QF SKGKT KRL I I D LF GMKRMWD I GNKHL

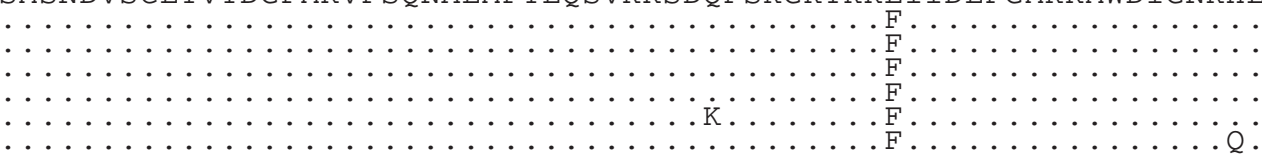

EDENLDETVGVADLGLVKYLINNKYDEAEKTSLRKSMEEAFEKSMNEEFVVLNKGKSANDI IS

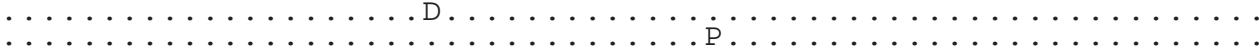

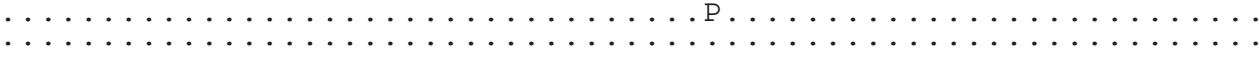

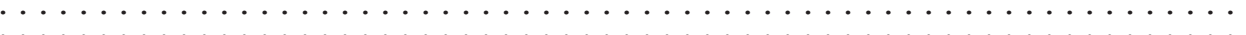
DTNAMCKF CVKNWIVATGFRGRTMSDLIEHHFRCMQGKQEVKGY IWKHKYNERLKRKQLSKEE

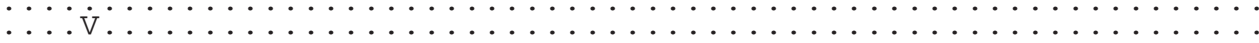

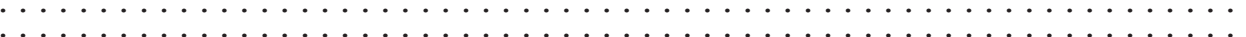

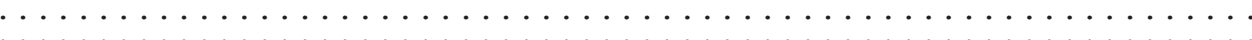

premotif A

VKFDREEYTSRSFRLLSF LKNSERTKLEPRAVFTAGVPWRAF IFVLEQTMLVVNKLDPNSVIL $\ldots \ldots \ldots \ldots \ldots \ldots \ldots \ldots \ldots \ldots \ldots \ldots$

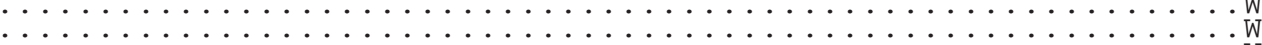

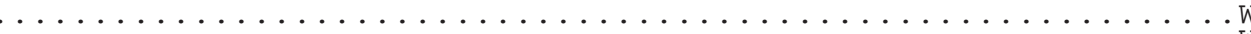

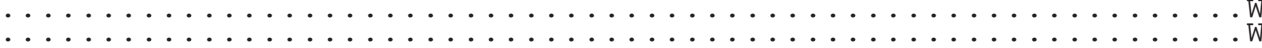
motif $A$

DGSDAKINTTNSRIKEI GMKNQ GQTLVTLTGDNSKYNESMCPEVMMIF LRELG IKGPMLEVLD

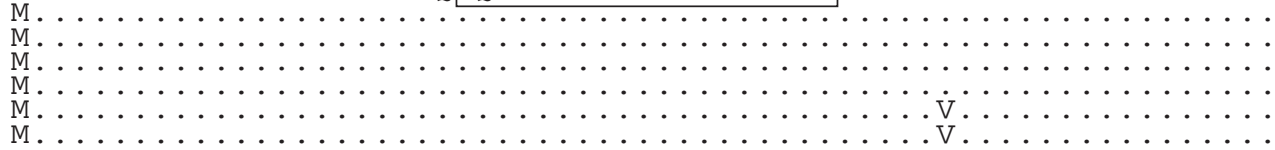

YALWQF SQKSVKPVAP IKKRTSRSTVVVKADAVNECRDAFNEKELELIQGVEWMEDGFIRVRR

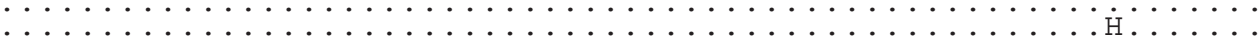

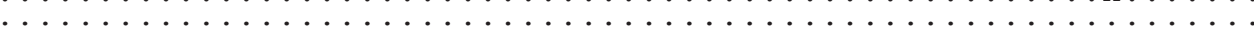

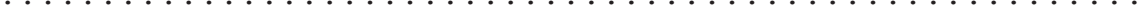
motif $B$ motif $C$

GMLMGMANNAFT TAST IASSF SF TP EAVYTLQSSDDFVTGSCGRDVQHARQRLEMALKVSKAA

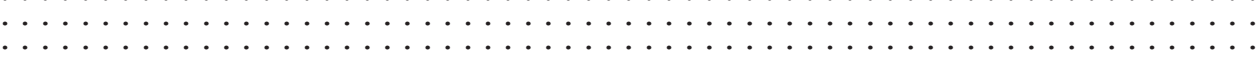
$\ldots$ a

motif $D \mid$ motif $E$ GLNVSQKKSFYVEGT TFEFNSMFVRD GKVMANGGNFEN I TVP GGLGP S TD LFVVGKQARNSML

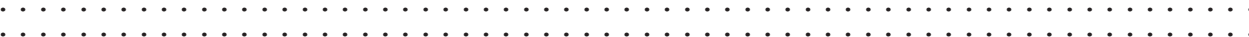

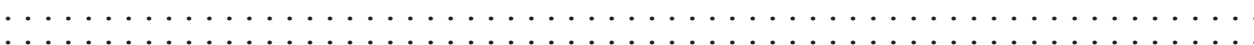
RGNLSF SQAMEMCK I G I TNVEKVYYGNRKYQELKNE I REKCGEETMS IP E SMGGDRKPKPWEL

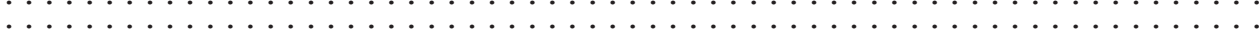

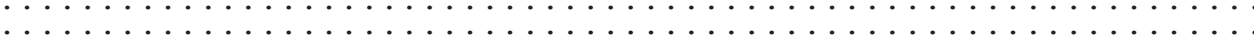
PQSFDGIALKEAVNRGHWKAAKYIKSCCSIEFDEEGDOSWDTSKTALVVIRKNEIDMRRRTVK

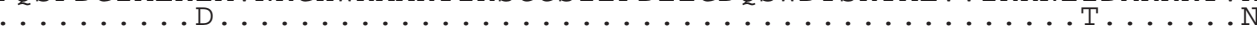

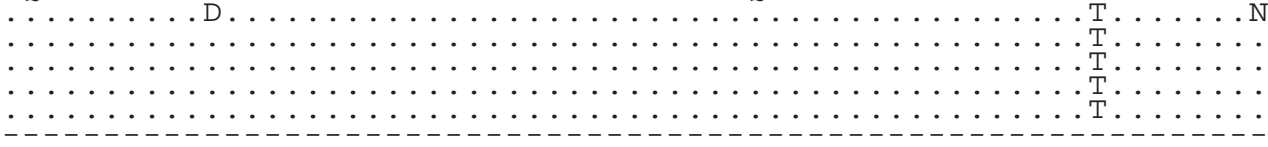

TRNP KDKIFNDAVNKAKRMYETVVDRNP LLGLKGKGGRLTVKDLKARKL I DEVEV IKKKKHV

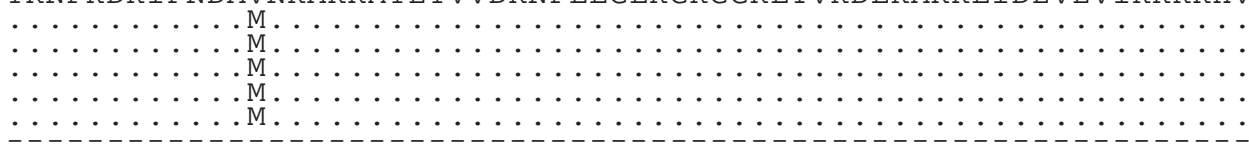


Fig. 1. Putative amino acid sequence alignment of ISAV segment 2 for Scottish (AJ242808 and 1490/98), Norwegian (AJ002475, ILA 8, ILA10 and ILA36) and Canadian isolates (AF095254). . : sequence identical to AJ242808. -: missing data. Polymerase motif regions identified by Krossøy et al. (1999) are outlined

gence. In commercial aquaculture where the fish are maintained at high density, the opportunity for virus transmission and epidemic infection is greatly increased. The salmon farm situation may more closely resemble the mammalian and avian pattern and will have different selection pressures operating on the virus. Within the Scottish isolates from farmed salmon, no divergence was noted. However, these isolates have a point source and were obtained within a short time of each other, and therefore divergence is unlikely. Most of the Norwegian isolates were widely separated in both time and geographical situation and so the sequence variation found is not unexpected. Isolates AJ002475 and Sotra/B797/92 originate from the same location, but it is uncertain whether they are in fact the same isolate.

Norwegian Sotra/B797/92 and Hinnøy/2264/93 isolates appear identical at the amino acid level, demonstrating that nucleotide variation, although useful for epidemiological study, is not representative of changes in the protein. It is not clear whether the alterations in protein sequence caused by the amino acid differences are significant in relation to the structure and function of the virus particle. Further work may determine if these changes affect the pathogenicity of the virus. All the isolates show the conserved motifs found in all negative stranded RNA polymerases, including the SDD sequence in motif $C$ and the EFXS sequence in motif E (Krossøy et al. 1999). The European isolates show no variation within these motif regions, while the Canadian region shows variation in motif region $B$. Other segments are likely to show the same pattern, with variation falling outwith the conserved regions. Once the function of the NS protein has been determined, it may be possible to identify conserved regions in segment 8 and subsequently, the position of the 3 nucleotide differences.

The sequence variations revealed here do not provide any clear information as to the origin of ISAV in Scotland. It may be the case that there is a pool of the virus circulating in the marine environment. Such a pool could contain many genetic variants, as is the case for VHSV (Snow et al. 1999). The high degree of sequence variation between European and Canadian strains within a pool of virus could reflect either geographical or temporal separation. Analysis of many more ISAV isolates or isolates gathered over a long time span may reveal which factor is most influential in sequence variation.
At present it is impossible to predict whether the variable strains of ISAV may have differing pathogenicity or immunogenicity. Given the 'quasispecies' nature of RNA viruses such as viral haemorrhagic septicaemia virus (VHSV) (Béarzotti et al. 1995) it is not surprising that sequence variants should exist. Determination of the relationships between genotype and phenotype requires large scale and labourintensive studies beyond the scope of the present study. Nevertheless, the different genotypes revealed here could be useful in epidemiological studies.

Acknowledgements. The authors wish to thank Dr K. Falk, National Veterinary Institute, Oslo, for supplying ISAV isolates from Norway and members of the Molecular Genetics Group for assistance during this study.

\section{LITERATURE CITED}

Béarzotti M, Monnier AF, Vende P, Grosclaude J, deKinkelin P, Benmansour A (1995) The glycoprotein of viral haemorrhagic septicaemia virus (VHSV); antigenicity and role in virulence. Vet Res 26:413-422

Blake S, Bouchard D, Keleher W, Opitz M, Nicholson BL (1999) Genomic relationships of the North American isolate of infectious salmon anemia virus (ISAV) to the Norwegian strain of ISAV. Dis Aquat Org 35:139-144

Cunningham CO, Snow M (2000) Genetic analysis of infectious salmon anaemia virus (ISAV) from Scotland. Dis Aquat Org 41:1-8

Dannevig BH, Falk K, Namork E (1995) Isolation of the causal virus of infectious salmon anemia (ISA) in a long-term cell line from Atlantic salmon head kidney. J Gen Virol 76: 1353-1359

Falk K, Namork E, Rimstad E, Mjaaland S, Dannevig B (1997) Characterisation of infectious salmon anaemia virus, an orthomyxo-like virus isolated from Atlantic salmon (Salmo salar L.). J Virol 71:9016-9023

Hastings T, Olivier G, Cusack R, Bricknell I, Nylund A, Binde M, Munro P, Allan C (1999) Infectious salmon anemia. Bull Eur Assoc Fish Pathol 19:286-288

Jarp J, Karlsen E (1997) Infectious salmon anaemia (ISA) risk factors in sea-cultured Atlantic salmon Salmo salar. Dis Aquat Org 28:79-86

Krossøy B, Hordvik I, Nilsen F, Nylund A, Endresen C (1999) The putative polymerase sequence of infectious salmon anemia virus suggests a new genus within the Orthomyxoviridae. J Virol 73(3):2136-2142

Krystal M, Buonagurio D, Young JF, Palese P (1983) Sequential mutations in the NS genes of influenza virus field strains. J Virol 45:547-554

Melville KJ, Griffiths SG (1999) Absence of vertical transmission of infectious salmon anemia virus (ISAV) from individually infected Atlantic salmon Salmo salar. Dis Aquat Org 38:231-234 
Mjaaland S, Rimstad E, Falk K, Dannevig BH (1997) Genomic characterization of the virus causing infectious salmon anemia in Atlantic salmon (Salmo salar L.): an orthomyxolike virus in a teleost. J Virol 71:7681-7686

Mullins JE, Groman D, Wadowska D (1998) Infectious salmon anaemia in salt water Atlantic salmon (Salmo salar L.) in New Brunswick, Canada. Bull Eur Assoc Fish Pathol 18: $110-114$

Nakajima K, Nobusawa E, Ogawa T, Nakajima S (1987) Genetic divergence of the NS genes of avian influenza viruses. Virology 158:465-468

Rimstad E, Falk K, Mikalsen AB, Teig A (1999) Time course tissue distribution of infectious salmon anaemia virus in experimentally infected Atlantic salmon Salmo salar. Dis Aquat Org 36:107-112

Rodger HD, Turnbull T, Muir F, Millar S, Richards RH (1998) Infectious salmon anaemia (ISA) in the United Kingdom. Bull Eur Assoc Fish Pathol 18:115-116

Editorial responsibility: Jo-Ann Leong,

Corvallis, Oregon, USA
Snow M, Cunningham CO, Melvin WT, Kurath G (1999) Analysis of the nucleoprotein gene identifies distinct lineages of viral haemorrhagic septicaemia virus within the European marine environment. Virus Res 63:35-44

Stagg R, Bruno D, Cunningham C, Hastings T, Bricknell I (1999) Focus on infectious salmon anaemia: epizootiology and pathology. State Vet J 9:1-5

Suarez DL, Perdue ML (1998) Multiple alignment comparison of the non-structural genes of influenza A viruses. Virus Res 54:59-69

Thompson JD, Higgins DG, Gibson TJ (1994) CLUSTAL W: improving the sensitivity of progressive multiple sequence alignment through sequence weighting, position-specific gap penalties and weight matrix choice. Nucleic Acids Res 22:4673-4680

Thorud K, Djupvik H (1988) Infectious anaemia in Atlantic salmon Salmo salar L. Bull Eur Assoc Fish Pathol 8: 109-110

Submitted: April 26, 2000; Accepted: August 25, 2000 Proofs received from author(s): October 16, 2000 